\title{
Staj Deneyiminin Kariyer Seçimine Etkisi: Trakya Bölgesi'ndeki Turizm Öğrencilerine Yönelik Bir Araştırma ${ }^{1}$
}

\author{
DOI: 10.26466/opus.533956
}

\author{
Bayram Akay* - Seher Sittak ${ }^{* *}$ \\ *Dr. Öğr. Üyesi, Burdur Mehmet Akif Ersoy Üni.Turizm Rehberliği Bölümü, Burdur / Türkiye \\ E-Posta: bakay@mehmetakif.edu.tr ORCID: 0000-0003-4658-6994 \\ ** Yüksek lisans Öğrencisi, Kırklareli Üniversitesi, Sosyal Bilimler Enstitüsü, Kırklareli / Türkiye \\ E-Posta: $\underline{\text { s.sittak15@gmail.com }}$ \\ ORCID: 0000-0002-4290-437X
}

\section{Öz}

Turizmin uluslararası ve ulusal baz da genişlemesiyle turizmde çalışacak kalifiyeli eleman ihtiyacı her geçen gün artmaktadır. Ülkemizde turizm eğitimi veren birçok üniversite bulunmasına ve her yıl turizm mezunu verilmesine rağmen yine de sektör bu işin eğitimini almış profesyonel insan gücü bulmakta sıkıntı çekmektedir. Araştırmanın amacı, Trakya bölgesinde (Kırklareli - Edirne - Tekirdă̆) turizm eğitimi alan önlisans ve lisans öğrencilerinin staj deneyimlerinin kariyer seçimlerine etkilerini tespit etmektir. Araştırmanın alt amaçları; öğrencilerin sektöre yönelik algılarını, sektöre karşı tutumlarınl, sektörde kariyer yapma eğilimlerini ve staj motivasyonların belirlemektir. Araştırmada nicel araştırma yöntemlerinden anket tekniğgi kullanılmıştır. Araştırmanın evreni, Kırklareli Turizm Fakültesi ve Pınarhisar MYO, Trakya Üniversitesi Uygulamah Bilimler Yüksek Okulu ve Tekirdağ Namık Kemal Üniversitesi Sosyal Bilimler MYO Turizm ve Otel işletmeciliği önlisans ve lisans öğrencileri oluşturmaktadır. Araştırmanın örneklemini turizm eğitimi gören ve en az bir kere staj yapmış 215 lisans ve 90 önlisans öğrencileri oluşturmaktadır. Sonuç olarak, staj motivasyonu, iş ortamı, eğitim ve sektöre uyum değişkenlerinin kariyer seçimi üzerindeki ilişkisi anlamlı olduğu saptanmıştır.

Anahtar Kelimeler: Turizm, Kariyer Seçimi, Trakya Bölgesi, Staj.

\footnotetext{
${ }^{1}$ Bu çalışma, 01-03 Kasım 2018 tarihindeki I. Uluslararası Turizmde Yeni Jenerasyonlar ve Yeni Trendler Kongresi (INGANT)'nde sunulmuş bildirinin genişletilmiş halidir.
} 


\title{
Effect of Internship Experience Career Choice: A Research on tourism students in the Thrace Region
}

\begin{abstract}
With the expansion of tourism in an international and national basis, the need for qualified staff to work in tourism is increasing day by day. Although there are many universities that provide tourism education in our country and a students graduate from tourism faculties every year, the sector still suffers from having the professional labor force that has received education on this business. The purpose of the study is to determine the effects of internship experiences of undergraduate and graduate students receiving tourism education in Turkey's Thrace region (Kırklareli - Edirne - Tekirdağ) on their career choices. Sub-objectives of the research are to define the students' perceptions towards the sector, attitudes towards the sector, tendencies to make a career in the sector and motivation of internship. Survey technique from the quantitative research methods have been used in the research. The universe of the research is composed of the associate and undergraduate students of Kirklareli Tourism Faculty and Pınarhisar Vocational School, Trakya University Applied Sciences Academy and Tekirdăg Namık Kemal University Social Sciences Vocational School Tourism and Hotel Management, located in Thrace region. The sample of the research consists of 215 undergraduate and 90 associate degree students. The research questionnaire has been applied to students who have been trained in tourism and completed at least one internship. As a result, the effect of motivation of internship, job environment, education and sectoral adjustment variables on career choice is significant.
\end{abstract}

Keywords: Tourism, Career Selection, Trakya Region, Internship 


\section{Giriş}

1980'li y1llardan itibaren gelişim gösteren turizm sektörü ülkeler için önemli bir sosyo- ekonomik faaliyet alanı oluşturmuştur. Turizm sektörünün hızla gelişmesi ve uluslararası boyuta ulaşması ise sektörün cazibe unsurlarını ortaya çıkarmakta ve böylece turizmin geliştirilmesi ve ülkeye daha fazla getiri sağlaması için turistik işletmeler çoğaltılmakta, yatırımcılar için fırsatlar sağlanmaktadır. Ülkemizde turizm sektörü özellikle 2000'li yıllardan sonra büyük gelişme göstererek uluslararası rekabet edilebilirliğin yüksek olduğu sektörlerden biri haline gelmiştir (Günay ve Akınc1, 2017, s.2). Ülkemize gelen turist sayısı 2010 yılında 33.027 .943 kişi ve turizm geliri 24.930 .997 dolar iken, 2018 yılı itibari ile turist sayısında 39.556.496 kişiye ve turizm gelirleri de 29.512.926 dolar'a ulaşmıştır (TÜRSAB, 2019). Geçen yıl içerisinde turist sayısında \% 13,6, turizm gelirlerinde ise $\% 7,3$ artış olmuştur.

Turizm sektörü geçmişten günümüze hem gelişmiş hem de gelişmekte olan ülkeler açısında büyük önem taşımaktadır. Küresel turizm hareketlerindeki yükseliş ve buna paralel olarak sektörün ekonomik açıdan hızlı bir şekilde gelişmesi, turizmi günümüzün en önemli sosyal ve ekonomik değerlerinden biri haline getirmiştir (Fong vd., 2014, s.68). Turizm gelişmiş ve gelişmekte olan ülkelerde farklı alanlarda değerlendirilmiştir. Gelişmiş ülkeler genellikle turizmin gelir yaratıcı etkisinden yararlanırken gelişmekte olan ülkeler ise istihdam, döviz girdisi ve iç ödemeler dengesi özelliklerinden yararlanmaktadır. Bu yüzden ülkelerin çalışan personel kalitesine önem verdiği görülmektedir.

Turizmde işgören üzerinde kalitenin sağlanması; personel ve stajyerlerin meslek eğitimlerinin niteliği, kişilerin beklenti ve istekleri sektörde karşılanarak kariyer geliştirme fırsatı sağlaması yoluyla gerçekleşebilir (Gürdoğan vd., 2015). Son yıllarda teknolojinin hızla gelişmesi ve her alanda kullanılabilir hale gelmesi bazı sektörlerde insan gücünü geri planda bırakmıştır. Ancak turizm endüstrisinde teknolojik gelişmelerden yararlanma imkanları diğer sektörlere göre sınırlılık göstermektedir. Hizmetlerin müşteri istek ve ihtiyaçları doğrultusunda oluşturulup sunulması sektörün emek-yoğun özelliğini önemli ölçüde etkilememiştir.

Son yıllarda turist memnuniyeti ve sadakati sağlamak için turizm eğitimi almış kalifiyeli elemanları işletmeye çekme ve işletmede tutmanın 
önemi artmıştır. Ancak dünya genelinde turizm endüstrisi, kaliteli çalışanların ilgisini çekmek ve elde tutmak problemiyle her zaman karşı karşıya kalmaktadır (Richardson vd., 2012, s.262).

Türkiye turizm gelirleri 2018 yılı itibari ile yurtiçi GSMH \%3,8'ini içermekte ve ülkenin dış ticaret açı̆̆ının \%35'e yakın olan kısmını karşılamaktadır (TURSAB, 2019). Ülkemizde 2018 y1lı içinde \% 11,6 olan işsizlik oranının dolaylı ve doğrudan $\% 54,9^{\prime}$ luk kısmını turizm ve hizmet sektörü karşılamaktadır (TUIK, 2019). Turist sayısında ve harcamalardaki artış ile Seyahat ve Turizm, \%3,9'luk küresel büyüme oranı ile 2018 yılında doğrudan toplam istihdamın \% 7,7'sini karşılarken, 2028 yılına kadar toplam istihdamda \% 2,8'lik bir artış olacağ tahmin edilmektedir (WTTC Türkiye raporu, 2019). Belirtilen verilere göre turizm ülke ekonomisi için önemli bir istihdam alanıdır. Turizm alanında mesleki yeterliliğe ulaşmış ve eğitimini tamamlamış bireylerin sektörde istihdam edilmesi, bilgi, beceri ve deneyimlerini iş alanında uygulamaları sektörün daha bilinçli ve yenilikçi olarak gelişmesini sağlayacaktır. Turizm sektörünün iş olanaklarının geniş olması ve çeşitlilik göstermesi kalifiye personele olan ihtiyacı da artmakta ancak sektörde iş deneyimine sahip olan kişilerin alg1 ve tutumlarının değişmesi mesleklerinde kariyer yapma isteğini de etkilemektedir. Richardson, (2008, s.27) Doğrudan deneyime dayalı alg1 ve tutumların, insanların sektöre daha güçlü ve gerçekçi bir bakış açısıyla bakacağını ve bu nedenle gelecekteki davranışları daha fazla tahmin edeceği görüşündedir.

Bu çalışmanın amacı ise, Trakya bölgesinde (Kırklareli - Edirne Tekirdağ) turizm eğitimi alan önlisans ve lisans öğrencilerinin staj deneyimlerinin kariyer seçimlerine etkilerini tespit etmektir. Bu bağlamda elde edilen bulgularla öğrencilerin staj deneyimi sürelerinde elde ettikleri tecrübelerin kariyer seçimlerinde ki etkisini ortaya koymak ve staj dönemlerine ilişkin iyileştirme ve güçlendirmeler yapılmasında katkı sağlayacağ1 düşünülmektedir.

\section{Turizmde Staj Eğitimi}

Her meslek dalında olduğu gibi turizm eğitiminde de stajlar kişileri geleceğe hazırlamak, misyon belirleme, teorik bilgiyi pratiğe dökme, bilgi, 
beceri ve donanım kazandırması bakımından önem taşımaktadır. Öğrencilerin staj eğitimi süresinde iş - yaşam, yaşam - iş hayatına uyum sağlayabilme arasında somut bir deneyim kazanmaktadırlar. Tanım olarak staj; pratik çalışma deneyimi, işe yerleştirme, profesyonel yetiştirme, işbirlikçi eğitim ya da deneyimsel öğrenim faaliyeti olarak da adlandırılan, öğrencilerin eğitim aldıkları ve aynı zamanda deneyim kazanabildikleri kısa süreli pratik iş dönemleridir (Koç vd., 2014, s.137). Türk Dil Kurumu'na göre staj; "Herhangi bir iş edinecek olan bireylerin geçirdiği uygulamalı öğrenme dönemi" ya da "bir kimsenin meslek bilgisini artırmak için bir kurumun bir veya birçok bölümünde çalışarak geçirdiği dönem" olarak tanımlamaktadır (TDK, 2018). Staj, kişinin eğitimini aldığ1 meslek veya sanat dalıyla ilgili alanında gelişme ve iş yordamı öğrenmesi amacıyla gerçekleştirilen etkinliktir (Güzel, 2010). Stajın amacı ise; mesleği yerinde tanıma, sektörel deneyim, geniş bir perspektif açısı ve eğitim - hizmet ilişkisinin kurulmasıdır.

Turizmde staj turistlere sunulan bütün üretim ve hizmetlerin sunulmasını pratik yaparak öğretme, kalifiye eleman yetiştirme, bilgi - beceri geliştirme, güncel konuları takip etme ve donanım kazanma faaliyetlerinin tümünü kapsamaktadır. Eğitim kurumlarında verilen teorik eğitimin pratik bilgi ile arasında olan boşluğu kapatmak ve kariyer seçimlerini yapmak için iyi bir fırsat (Barbarash, 2016, s.29) olmasına rağmen staj uygulamaları, konunun odak noktasında kişinin kendisi ve gelecekteki kariyeri bulunduğu için işletme ve eğitim kurumları tarafından farklı açılardan değerlendirilmektedir (Demir ve Demir, 2014, s.21).

Francis ve Alagas (2017) göre öğrenciler için stajin olumlu yönü çalışma psikolojisini yaşaması, olumsuz yönü ise işletmede değer görmemeleridir. Buna göre staj eğitimi, iş hayatını yerinde deneyimleme, sorun ve zorluklara pratik çözümler geliştirebilme, müşteri istek ve ihtiyaçlarını karşılayıp müşteri memnuniyeti elde etme, örgüt içi iyi iletişim kurabilme ve takım çalışmalarına uyum sağlayabilme, gözlem ve çıkarım yapabilme gibi birçok tecrübe ve bilgiler kazandırmaktadır. Bu sayede kişinin kendine olan güveni, bilgi birikimi ve tecrübesini arttıracak, kişi kendini daha donanımlı ve gelişmeye açık hissederek kariyer isteklerine uygun tutum ve standartlar geliştirebileceklerdir. Ayrıca sektöre yönelik yenilikleri tanımasıyla birlikte çalışma yaşamında da önemli referanslar elde etmiş olacaklardır (Çetin, 2005). Staj eğitimini tamamlayabilmeleri 
için öğrencilerin kendi çabaları ile işletme bulmaları ve yaşadıkları zorluklar, işletme yöneticilerinden destek ve takdir görmemeleri, işletme de eğitim almanın dışında ucuz işgüçü olarak görülmeleri ve öğrenilen ile işle ilgili deneyim arasındaki tutarsızlıklar kişilerin olumsuz algılarına neden olmaktadır (Koç vd., 2014). Staj uygulamaları işin gerçek doğasını görmek, iş yaşamındaki farklılıkları tanımak ve kişiler için mesleklerinde devam etmeleri ya da vazgeçmeleri hususunda önemli rol oynamakta, kariyer seçiminde bir dönüm noktası olmaktadır.

\section{Turizmde Kariyer}

Turizm hızla büyüyen bir sektör ve büyük bir istihdam kaynağıdır. Turizm ve ilgili istihdamın büyümesi, dünya çapında birçok ülkede üretimden hizmet ekonomisine kadar geniş çaplı değişimin bir parçası olarak görülmektedir. Bununla birlikte, endüstrinin gelişimi yeni istihdam olanakları yaratsa da, çoğu zaman bireyler de; düşük iş tatmini sunan, vasıfsız ve düşük ücretli işler için uzun çalışma saatleri gerektiren bir meslek olarak algılanmaktadır (Roney ve Öztin, 2007, s.5).

1950'li yıllarda akademik yazında görülmeye başlanan kariyer hem kişi hem de işle ilişkilendirilen bir kavramdır. Bireylerin yaşamlarında vereceği birtakım kararlar dizisinin en önemli unsuru duruma göre değişkenlik gösterebilen faktörlerden etkilenerek iş yaşamları üzerindeki mesleki tercihleridir. Bireyin bu tercihleri mesleki kariyer gelişiminin de tetikleyicisidir. Kişinin yapmak isteyeceği meslek, onun nasıl bir hayat sürmek istediğini, hedefini, kişilik gelişimini, potansiyelini kullanmayı becerebilmesi, kendine olan inanc1, saygısı, mesleki doyum, maddi kazancı ve zamanını kullanabilme tarzını oluşturur. Dolayısıyla kariyer; mesleki ve iş yaşamında ilerleme, başarıya ulaşma ve kişinin bütün iş süreci boyunca yerine getirdiği rolleri ile ilgili tecrübeler bütünüdür (Gündoğan ve Atabey, 2015). Kariyer seçimi kişinin iş yaşamında başarı sağlayabilmesi ve işini devam ettirebilmesi için de büyük önem taşımaktadır.

Öğrencilerin staj sırasında kazandıkları deneyimi 'iş motivasyonu, işyerine karşı tutum, eğitim ve sektörel uyum, iş doyumu ve iş ortamı' değişkenleriyle ile açılamak mümkündür. 
Motivasyon; Motivasyon faktörü bireylerarası ve işletmenin işgörene karşı tutum ve davranışlarının farklılık göstermesine göre algılanması da farklılık göstermektedir. Genel olarak motivasyon; kişi veya kişileri, belirli bir yöne - amaca doğru sürekli bir şekilde harekete geçirme konusunda yapılan çabalar toplamıdır (Ergül, 2005, s.69). Motivasyon olmadan başarmak, daha ileriye gidebilmek için harekete geçmek imkansızdır. Bu sebeple başarının etkili yolu motivasyonu sağlanmış bireylerdir. Turizm işletmelerinde de teknolojinin gelişmesi sektöre yansımış olsa dahi ana unsur işgören emeğidir. Motivasyon çalışanla birlikte örgütün performansında da önemli role sahiptir. İşini severek yapan, yaptığı iş karşıllı̆̆ memnun olan ve başarı odaklı bireyler, çalıştığı işletmelerdeki verimliliğin artması konusunda gerekli destek ve katkıyı sağlayabilme yetkinliğindedirler. Çalışanların yüksek mesleki motivasyona sahip olmaları, işletmelerde kurum içi etkileşimi arttırmakta ve yenilikçi iş davranışları geliştirme konusunda da başarıya ulaşmalarında önemli etkendir.

Turizm hizmetlerinin üretildiği anda tüketilmesi sürekli olarak müşteri - çalışan diyaloglarını geliştirmektedir. Bu yüzden de motive olmuş bir çalışan işletmenin verimliliğini arttırmak için daha fazla faaliyette bulunacak ve emek harcayacaktır. Sektörde ekonomik faktörlere nazaran çalışanın psiko- sosyal yönde motivasyonlarının sağlanması daha önemlidir. İşletmelerde çalışan bireylere gerekli fiziksel donanım, destek ve kendini gerçekleştirme imkanlarının verilmesi, ödül ve jestlerle işletmeye bağlılıklarının arttırılmaya çalışılması işgörenin kendine değer verildiğini hissetmesini sağlayacak ve örgüte olan bağlılığını arttıracaktır. İş yaşam kalitesi genel olarak yaşam kalitesini de doğrudan etkilemektedir. Kişilerin iş yaşamları boyunca başarılı olabilmeleri ve işte uzmanlaşmalarının temelinde motivasyon bulunmaktadır. $\mathrm{Bu}$ durum eğitimlerinin bir parçası olan stajyer öğrenciler için de önem taşımaktadır. Çünkü sektörün iş yaşam döngüsünü staj yaptıkları süre de tanıyan öğrencilerin çalışma dönemlerinde mutsuz ve huzursuz olmaları, yoğun ve zor şartlar altında çalıştırılmaları, az miktarda ücret almaları yaşam kalitesini etkileyerek bireylerin motivasyonunu düşürmekte (Aslan vd., 2014, s.169) ve sektörden uzaklaştırmaktadır.

İşyerine Karşı Tutum; Turizm öğrencilerinin eğitim hayatlarının belirli dönemlerinde işletmelerde çalışarak orada sahip oldukları bilgi, tecrübe, 
alg1 ve sektöre karşı duygu ve düşünceleri işe ve işyerine karşı olan tutumlarını önemli ölçüde etkilemektedir. Tutum, işyerine karşı oluşturulan hisler, duygu ve düşünceler, inançlar ve bağlllıklara karşı oluşturulan bütün sezinlemelerdir. İşgörenlerin işletmeye karşı tutumlarının oluşmasında 'inançlar, hisler, duygusal süreçler ve davranışsal niyetler' önemli rol oynamaktadır. Çalışanların işe ve işyerine karşı tepkileri ise tutumlarını oluşturur. İşletmeler ise işgörenin isteklerinden ziyade rakipleriyle rekabet üstünlügü sağlama çabasında oldukları için çalışan memnuniyeti ve işletmede devamlılı̆g hususunda kişisel gelişimi destekleyici faaliyetlere fazla zaman ayırmamaktadırlar. Oysa ki işverenler işgörenler üzerinde olumlu ve örgütsel bağlılıkları artırıcı davranış ve etkinlikler de bulunarak işletmeye karşı tutumlarını artırmalıdırlar. Turizm işletmelerine karşı işgörenlerin iş tutumu diğer iş alanlarına göre daha çok önemsenmektedir. Kişiliğin kullanımı, güler yüz, nezaket, içtenlik, insan sevgisi ve saygı, temizlik, yardımseverlik, anlayış, hoşgörü gibi tutum ve alışkanlıkların düzeyi, kullanılma şekli müşterilerin temel psikolojik beklentilerinin karşılanmasında ilk sırada yer almaktadır (Tarlan ve Tütüncü, 2001, s.146). Çalışanların sektöre ve işletmelere yönelik tutumlarını inceleyen araştırmalardan bazıları işgörenin olumlu tutumlarını belirtirken genel itibari ile çalışanlarda sektöre karşı olumsuz tutum içinde oldukları belirtilmektedir. Bunun nedeni ise sektörün kırılgan yapısı ve ekonomik gelir yeterliliği bakımından tatmin edici olmayışıdır.

İşgörenler üzerinde terfi, yüksek ücret, başarılarının desteklenmesi ve örgütün varlığını arkasında hissetmeleri çalışanların işe bağlılıkları arttıracak ve tutumlarını olumlu yönde geliştirecektir. İşgörenin olumlu tutumları daha fazla çalışma isteği, işiyle ilgili yenilikleri takip ederek işyerinde uygulama ve işletmeyi bir adım daha öteye nasıl taşırım? düşüncesiyle hareket ederek işyerine karşı benlik algısı oluşturarak iş performansını arttırma yönünde gerçekleşecektir.

Eğitim ve Sektörel Uyum; Literatürde birden fazla tanımla açıklanan eğitim, kişilerin içinde bulundukları ortam ile uyumlu bir biçimde yaşayabilmeleri için gerekli bilgi ve davranışların kazanılmasıdır (Çetin, 2005, s.154). Kişilerin hayatlarını devam ettirebilmeleri için bir mesleğin eğitimine ihtiyaçları vardır. Bu bağlamda mesleki eğitim ise, bireylerin iş alanlarındaki ilgili meslekleri ile el becerisi ve iş alışkanlıkları kazandıran, 
bireyin yeteneklerini farklı yönlerde geliştiren süreçtir (Sezgin, 1988, s.11). Mesleki eğitim dahilindeki turizm eğitimi ise, emeğe dayalı iş verimliliğini artırmak, turiste birebir hizmet vermek, personelin yetki, yetenek ve sorumlulukları arasında denge kurmayı sağlayacak davranışların kazanılmasını ile ilgilidir (Aksu ve Bucak, 2012, s.8). Turizm eğitiminin bir parçası olan stajlar da, öğrencilerin yaşadıkları sıkıntınlar meslek hayatına uyum sağlamalarını zorlaştırmakta, yaş, cinsiyet ve kişisel özellikler gibi faktörlerde sektöre yönelik bakış açılarını etkilemektedir. Saruhan (1986), yaptığı çalışmada, turizm eğitimi alan kişilerin, işletmelerde çalıştıkları süre zarfında uygulamada beceri eksikliği, yabancı dil bilgisinin zayıflığı ve misafirlerle iletişim kurmakta zorluk yaşamaları gibi yetersizliklerden dolayı sektöre uyum sağlayamadıkları sonucuna ulaşmıştır. Çetin (1990), yaptığı çalışmada ise öğrencilerin sektörle tanışma, takım arkadaşlarıyla koordineli çalışma ve tatil yapma fırsatı yakaladıkları için stajdan memnun olduklarını, stajın eğitim - öğretimi bütünleştirdiği düşüncesinde olduklarını ortaya koymuştur. Bu çalışmada da öğrencilerin insanlara hizmet etmekten hoşlandıkları ve sektörde bilgi ve becerilerini kullanabileceklerini, tempolu iş ortamı sevdikleri için turizm sektörüne uyum sağlayabildikleri fakat iş ortamı, genel memnuniyet ve çalışma koşulları bakımından olumsuz tutum içinde oldukları tespit edilmiştir.

İş Doyumu; Birçok insanın inandığı üzere iş doyumunun başarıyı arttırdığını söyleyebiliriz. İş doyumuna en rasyonel yaklaşımın iş doyumu ve başarı faktörünün birbiriyle etkileşen dairesel bir ilişki içinde olduklarıdır. İş doyumu; çalışanların işlerinden algıladıkları hoşnut ya da hoşnutsuzluk, işin özellikleri ile istekleri birbirini karşıladığı zaman gerçekleşmekte, iş beklentileri ve işin sağladığı ödülleri içerdiği için eşitlik kuramı ve psikolojik anlaşmayla da ilgili bir kavramdır (Tarlan ve Tütüncü, 2001, s.146).

Turizm işletmelerinde iş doyumsuzluğundan kaynaklı birçok sorun ve iş doyumsuzluğunu etkileyen pek çok göstergeler bulunmaktadır. Bunlar ise (Oral, 1997);

- İşletmelerde fazla mesai uygulanı ücretlerin ödenmemesi,

- Müşteri şikâyetlerinin artması,

- İşverenin işgörenin motivasyonunu arttırmaya yönelik çabalamamasi, 
- İşyerindeki donanım ve materyalin yetersizliği,

- İşs kazalarında artış,

- İssgörenin işe devamsızlığının artması,

- İşgörenin örgütsel destek algılamasının azalması,

- İşgören devir hızının yüksek olması,

- Hizmet karşllı̆̆ ücretin yetersizliği,

İşletmelerin üst düzeyde başarıyı ve uzun dönemli karlılı̆̆ı sağlayabilmeleri ancak çalışanların işlerine yönelik tutumları ve davranışları ile yakalayabileceği inancı, iş doyumunun önemini daha da arttırmaktadır. Bir işletmenin hedeflerine ulaşabilmesi için, çalışan üzerinde iş doyumunu sürekli olarak yüksek tutması gerekmektedir (Köroğlu, 2011, s.249). Buna bağlı olarak, yüz yüze ilişkilerin yoğun olarak yaşandığı ve işgören deviniminin yüksek olduğu turizm işletmelerinde personel eğitim ve kalitesinin geliştirilmesi iş doyumu daha önemli kılmaktadır. Kişinin iş yerindeki pozisyonu, kendine atfedilen sorumluluk ve işletme içi iletişim şekli iş doyumunu etkilemektedir. İşten duyulan doyumunun yüksek olması, daha verimli çalışmayı beraberinde getirirken kişilerin başka mesleğe yönelme arayışları içinde bulunmamasını da sağlamaktadır (Tarlan ve Tütüncü, 2001, s.142).

İş Ortamı; Turizm işletmelerinde hizmetler anlık geliştiği için bir hizmetin gerçekleşebilmesinde birden fazla kişiye ihtiyaç duyulmaktadır. Bu yüzden iş ortamının işgörenlerin takım çalışmasına uygun olmalıdır.

Çalışma koşulları ve iş ortamının bireyler ve davranışları üzerindeki etkisi, fiziksel çalışma alanı, çalışma saatleri ve ücret, iş sağlığı ve güvenliği, profesyonel kimlik, anlamlı iş, karara katılma, özerklik, yöneticiler ve diğer meslektaşlarla ilişkiler, etkili liderlik, karşıllklı güven, mesleki gelişim ve öğrenmenin teşvik edilmesi, fiziksel ve psikolojik güvenlik, etkili iletişim ve ekip çalışması etkenlerine bağlıdır (Seymen vd., 2017, s.405). Kuşluvan ve Kuşluvan (2000)'nın çalışmasında, öğrencilerin sektörün olumsuz çalışma koşulları, düşük ücret veya ücretsiz ek çalışma saatleri, ağır iş yükü, stajda oryantasyon sağlanmaması, rotasyonun olmaması, stajlarından sorumlu birinin bulunmaması, öğrencilerin beceri ve yeteneklerinin altında veya üstündeki işlerde çalıştırılmaları, okullualaylı çatışması, yöneticilerin de eğitimli eleman ile diğer çalışanlar arasında bir fark görmemesi iş ortamının olumsuz algılandığını 
göstermektedir. Öğrencilerin stajda karşılaştıkları olumsuzluklar nedeniyle, sektörde kariyer yapma motivasyonları düşerek ve sektörde çalışmaya sıcak bakmamaktadır (Çetin, 2005).

\section{Metodoloji}

Bu bölümde araştırma için oluşturulan model kapsamında araştırmanın amacı ve yöntemi, verilerin analizleri ve araştırma modeli bulgularına yer verilmiştir.

\section{Araştırmanın Amacı ve Yöntemi}

Araştırmanın amacı, Türkiye Trakya (Kırklareli - Edirne - Tekirdağ) bölgesinde turizm eğitimi alan önlisans ve lisans öğrencilerinin okul sürecinde aldıkları staj eğitiminin sektörde kariyer yapma seçimlerine etkilerini tespit etmektir. Araştırmanın alt amaçları; öğrencilerin sektöre karşı olan tutumlarını, sektörde kariyer yapma eğilimlerini ve staj motivasyonlarının kariyer seçimine etkisini incelemektedir.

Araştırmanın evreni, Trakya bölgesinde bulunan Kırklareli Turizm Fakültesi ve Pınarhisar MYO, Edirne Trakya Üniversitesi Uygulamalı Bilimler Yüksek Okulu ve MYO Tekirdağ Namık Kemal Üniversitesi Sosyal Bilimler MYO Turizm ve Otel işletmeciliği önlisans ve lisans öğrencileri oluşturmaktadır. Araştırmanın örnekleminde ise 225 lisans ve 90 önlisans öğrencisi olmak üzere toplam 315 öğrenci oluşturmaktadır. $2018 \mathrm{Ni}$ san - Mayıs aylarında yapılan araştırmada örnekleme yöntemi olarak tesadüfi olmayan örnekleme türü kasti örnekleme seçilmiştir. Bu bağlamda araştırma anket soruları turizm eğitimi gören ve en az bir kere staj yapmış öğrencilere uygulanmıştır.

\section{Verilerin Analizi}

Araştırmada nicel verilere ulaşmak için anket tekniği kullanılmış ve hazırlanan anketler öğrencilere yüzyüze görüşme yöntemi ile uygulanmıştır. Anket formu, Türker, Uçar ve Ateş (2016); Duman, Tepeci ve Unur (2006); Kuşluvan ve Kuşluvan (2003) ve Riegel ve Dallas (1998)'in çalışmaların- 
dan, motivasyon ölçeği ise Tobin Lopes (2006) ve Kırçı (2007)'nın çalışmalarından oluşturulmuştur. Anket üç bölümden oluşmaktadır. Anketin birinci bölümünde, öğrencilerin eğitim ve demografik özellikleri (yaş, cinsiyet, okuduğu bölüm ve öğrenim süreleri) belirlemek amacıyla ortaya konan ifadeler yer almaktadır. Anketin ikinci bölümünde, öğrencilerin turizmde kariyer yapma seçimlerini belirlemek amaciyla 5'li Likert ölçeğinde ( $1=$ kesinlikle katılmıorum ve $5=$ kesinlikle katılıyorum $) 7$ adet yargı yer almaktadır. Anketin üçüncü bölümde ise, staj yapmış öğrencilerin edindikleri bilgi ve tecrübe ışığında beş adet kontrol değişkeni olmak üzere (staj motivasyonu, iş doyumu, iş ortamı, işyerine karşı tutum ve eğitim ve sektörel uyum) toplam 21 maddelik değerlendirme soruları yer verilmiştir.

Araştırmadan elde edilen veriler SPSS 22 paket programindan yararlanılarak analiz edilmiştir. İfadelere güvenirlilikleri (Croncbah Alfa) ölçüldükten sonra yüzde ve frekans analiziyle çoklu regresyon analizi uygulanmıştır. Öğrencilerin staj deneyimlerinin alt faktörleri ile cinsiyet, eğitim türü gibi demografik değişkenler arasında anlamlı farklılıkları belirlemek için parametrik testlerden T- testi uygulanmış, yaş değişkenine göre farklılıkları tespit etmek için Anova testinden yararlanılmıştır. Araştırma sonucunda ölçeklere ilişkin güvenirlilik analizi sonuçları tablo1' de verilmiştir.

Tablo 1. Ölçeklere İlişkin Güvenirlilik Analizi

\begin{tabular}{lll}
\hline Faktörler & İfade Sayıları Toplamı & Cronbach Alfa \\
\hline Kariyer Seçim Ölçeği & 7 &, 729 \\
Staj deneyimleri & 21 &, 792 \\
\hline
\end{tabular}

$N=315$

Tablo 1'de araştırmada kullanılan ölçeklerin güvenirlilik katsayısı (cronbach alfa) yer almaktadır. (Kayış, 2005)'de belirttiği üzere Cronbach Alpha değerinin $(0,70)$ den büyük olması "ölçek oldukça güvenilir"; turizmde kariyer seçimi ölçeğinin güvenirlilik katsayıları ayrı ayrı hesaplanarak ile ölçeklerin oldukça güvenilir olduğu tespit edilmiştir. Alfa değerlerine bağlı olarak $0.60 \leq \alpha<0.80$ ise 'ölçek oldukça güvenilir', $0.80 \leq$ $\alpha<1.00$ ise 'ölçek yüksek derecede güvenilir' denilmektedir (Kayış, 2005). Ölçeklerin güvenilir olduğu bu çalışmada da bir kez daha tekrarlanmıştır. 


\section{Araştırma Bulguları}

Araştırmaya katılan öğrencilerin anketlere verdikleri yanıtların Cronbach Alfa (güvenilirlik) testi uygulandıktan sonra demografik özelliklerine ilişkin frekans ve yüzde analizleri uygulanmıştır.

Tablo 2: Demografik Özelliklere İlişkin Frekans ve Yüzde Analizi Demografik Özellikler

\begin{tabular}{llcc}
\hline & & $\mathrm{F}$ & $\%$ \\
\hline \multirow{2}{*}{ Eğitim Türü } & Lisans & 225 & 71,4 \\
& Önlisans & 90 & 28,6 \\
\hline Alan & Turizm ve Otel İşletmeciliği & 315 & 100,0 \\
\hline \multirow{2}{*}{ Cinsiyet } & Erkek & 174 & 55,2 \\
& Kadın & 141 & 44,8 \\
\hline \multirow{2}{*}{ Yaş } & $18-22$ & 155 & 49,2 \\
& 23-25 & 156 & 49,5 \\
& 26 ve üzeri & 4 & 1,3 \\
\hline
\end{tabular}

Araştırmaya katılanların \%71,4'ü lisans, \%28,6'si önlisans düzeyinde turizm eğitim görmekte ve örneklemdeki bütün öğrenciler turizm ve otel işletmeciliği alanında öğrenim almaktadırlar. Söz konusu öğrencilerin $\% 55,2$ 'ni erkek \%44,8'ni kadın oluşturmaktadır. Yaşa göre dağılımında; en yüksek \%49,5 ile 23-25 yaş aralığı oluştururken, en az ise; \%1,3 ile 26 ve üzeri yaş aralığı oluşturmaktadır.

Ankete katılan öğrencilerin kariyer seçimlerine etkisi olduğu düşünülen staj deneyimi alt faktörlerinin birbiri ile olan ilişkisini ortaya koymak amacıyla faktörlere kariyer seçimi bağımsız değişkeniyle birlikte Tablo 3'de korelasyon analizi uygulanmıştır.

Tablo 3. Staj Deneyimlerini Açıklayan Faktörler Arası Korelasyon

\begin{tabular}{lcccccccc}
\hline Faktörler & Ort & s.s. & $\mathbf{1}$ & $\mathbf{2}$ & $\mathbf{3}$ & $\mathbf{4}$ & $\mathbf{5}$ & $\mathbf{6}$ \\
\hline 1. Staj Motivasyonu & 3,70 &, 793 & 1 & & & & & \\
2. İş̧ Yerine Karşı Tutum & 3,41 &, 628 &, $237^{* *}$ & 1 & & & & \\
3. İş Ortamı & 3,93 &, 752 &, $229^{* *}$ &, $302^{* *}$ & 1 & & & \\
4. İş Doyumu & 3,21 &, 732 &, $315^{* *}$ &, $319^{* *}$ &, $121^{*}$ & 1 & & \\
5. Eğitim ve Sektörel Uyum & 3,70 &, 818 &, $461^{* *}$ &, $205^{* *}$ &, $146^{* *}$ &, $232^{* *}$ & 1 & \\
6. Turizmde Kariyer Seçimi & 3,92 &, 684 &, $529^{* *}$ &, $223^{* *}$ &, $303^{* *}$ &, $273^{* *}$ &, $512^{* *}$ & 1 \\
\hline${ }^{*} p<0,01^{* *} p<0,05$ & & & & & & & &
\end{tabular}


Elde edilen korelasyon testi sonucuna göre öğrencilerin staj deneyimlerini ölçen alt faktörler arasındaki en yüksek korelasyonun 'İş yerine karşı tutum' ile 'İş ortamı' arasında oluştuğu $(r=, 302)$ görülmektedir. Pozitif yönlü ilişki olan iki faktör arasında öğrencilerin iş ortamını yerinde deneyimlemeleri ile edindikleri gözlem, algı ve çalışma koşullarının iyileştirilmesi hususunda çalışmalar yapmak iş yerine karşı olan tutumlarının da artmasını sağlayacaktır. Öğrencilerin kariyer seçimlerini etkileyen en yüksek faktör ise ilk 'staj motivasyonu $(\mathrm{r}=, 529)$ ' ikinci ise 'eğitim ve sektörel uyum $(\mathrm{r}=, 512)$ ' olarak gerçekleşmiştir.

Ankete katılan önlisans ve lisans öğrencilerinin staj deneyimlerini oluşturan faktörler ve bu faktörlerin turizm sektöründe kariyer seçimlerine etkisinin incelenmesi istenmiştir. Bu nedenle araştırma değişkenlerine çoklu regresyon analizi yapılmış ve analiz sonucu bulguları Tablo 4' de verilmiştir.

Tablo 4. Değişkenler Arasındaki Çoklu Regresyon Analizi

\begin{tabular}{|c|c|c|c|c|c|c|}
\hline Faktörler & B & S.H.B & $\beta$ & $p$ & $t$ & VIF \\
\hline Sabit & 8,310 & 1,515 & & & & \\
\hline 1. Staj Motivasyonu & 310 & ,062 & 269 &, $000^{*}$ & ,762 & 1,313 \\
\hline 2. İş Yerine Karşı Tutum &,- 060 & ,092 &,- 033 &, 519 & 822 & 1,217 \\
\hline 3. İş Ortamı & 253 & ,065 & 193 &, $000^{*}$ & 877 & 1,141 \\
\hline 4. İş Doyumu & ,132 & ,129 & 053 & ,308 & ,816 & 1,226 \\
\hline 5. Eğitim ve Sektörel Uyum &, 573 &, 082 & ,359 &, $000^{*}$ & 821 & 1,218 \\
\hline
\end{tabular}

Tablo 4 incelendiğinde oluşturulan modelin anlamlı olduğu ( $\mathrm{F}=33,978$; $\mathrm{P}=0,000$ ) sonucuna ulaşılmıştır. Bağımsız değişkenler araştırma modeline enter metodu ile dahil edilmiştir. Staj motivasyonu, iş ortamı, eğitim ve sektörel uyum değişkenlerinin bağımlı değişkene etkileri anlamlı iken; iş yerine karşı tutum ve iş doyumu değişkenlerin etkileri anlamlı değildir. Öğrencilerin sektörde kariyer seçiminin etkisi üzerinde (staj motivasyonu, iş ortamı, kişi ve sektörel uyum) bu üç değişkenin etkisi $\mathrm{p}<0,05 ; \mathrm{p}<0,000$ düzeyinde aynı orandadır. Modelin açıklanan 'Varyans Enflasyon Faktörü (VEF)' 10'un altında ve 'Tolerans Değerleri' 0,2'nin üzerinde olduğunda modelde bir sorun olmadığı anlaşılmaktadır (Günay ve Akınc1, 2017, s.13). Öte yandan Durbin - Watson değeri 1,811'in 2'ye yakın 
bir değer olduğu için regresyon modelinde oto- korelasyon olma şüphesini ortadan kaldırmaktadır. Regresyon modelerinde oto- korelasyon şüphesi Durbin- Watson değeri'nin $0-4$ arasında yer alması ve 2 değeri aldığında değişkenlerin hata terimleri arasında korelasyon olmadığını göstermektedir. Bu değer 2'nin üzerinde olursa hata terimleri arasında negatif korelasyon, 2'nin altında olursa pozitif korelasyon oluştuğu anlaşılmaktadır (Doğan ve Yılmaz, 2017). Bu nedenle D-W değerinin 2'ye yakın olması çoklu doğrusal regresyon modeli için oto- korelasyon şüphesini ortadan kaldırdığını söyleyebiliriz. Kariyer seçimine etki ettiği düşünülen değiş̧kenler arasında üç tahmini değişken ile pozitif yönde doğrusal ilişkisi bulunmuştur.

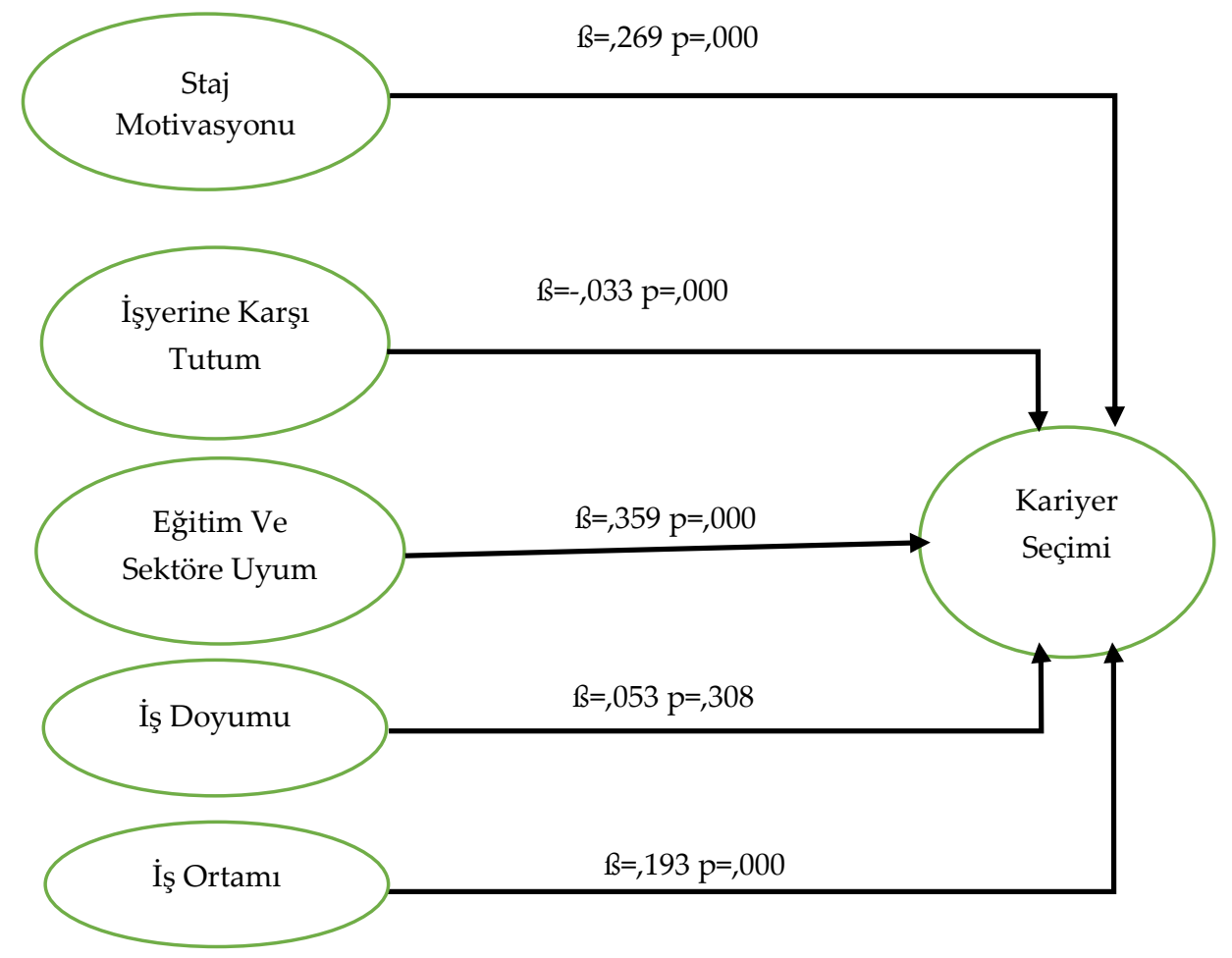

Şekil 1: Araştırma Modeli

Araştırmada birden fazla bağımsız değişkenin (staj motivasyonu, işyeri tutumu, eğitim ve sektöre uyum, iş doyumu, iş ortamı) bir bağımlı 
değişken (kariyer seçimi) üzerindeki etkisini incelemek için bir model oluşturulmuş ve modelin testi çoklu regresyon analiziyle yapılmıştır. Elde edilen sonuçlara göre modelin açıklama oranı \%37'dir. Staj motivasyonu, işyeri tutumu, eğitim ve sektöre uyum, iş doyumu, iş ortamının kariyer seçimine etkisi istatistiki açıdan anlamlıdır $(p=.000<, 05)$. Bağımsız değişkenlerin bağımlı değişkendeki önem sırası; eğitim ve sektöre uyum $(\beta=, 359)$, staj motivasyonu $(\beta=, 269)$ ve iş ortamı $(\beta=, 193)$ şeklindedir. Regresyon katsayılarına göre staj motivasyonu, iş ortamı ile eğitim ve sektöre uyum değişkenlerinin kariyer seçimi üzerindeki etkisi anlamlıdır (Sig.000<,05). İşyerine karşı tutumun ve iş doyumunun kariyer seçimi üzerinde anlamlı etkisi yoktur (Sig. 0,519-0,308>0,05).

Araştırma modeli sonuçlarına göre staj deneyiminin staj motivasyonu, eğitim ve sektörel uyum ile iş ortamı boyutunda öğrencilerin kariyer seçimine etkisi olduğunu gösterirken işyerine karşı tutum ve iş doyumunun kariyer seçimine etkisinin olmadığını göstermektedir. Öğrencinin staj süresindeki motivasyonu, iş ortamı ile eğitimi ve sektöre uyumu ileride kariyer seçimini etkilemektedir. Turizm eğitimi almış kişilerde sıkça görülen sektör değişikliğinin daha staj aşamasındaki bu etkenlerden kaynaklandığı söylenebilir. Dolayısıyla turizm işletmeleri yöneticilerine turizm eğitimi almış kişilerin sektörde kariyer yapması için gerekli hassasiyeti göstermeleri önerilebilir.

\section{Araştırma Modeli Değişkenleri İle Demografik Değişkenler Arasın- daki Farklılıklar}

Tablo 5'de öğrencilerin staj deneyimlerinden edindikleri motivasyon, iş doyumu, iş yerine karşı tutum, eğitim ve sektörel uyum ve iş ortamı değişkenlerine ilişkin belirtilen faktörler ile öğrencilerin cinsiyetlerinin arasında anlamlı bir farklılığın olup olmadığını ölçmek için T- testi yapılmıştır. Uygulanan analiz sonucunda kız ve erkek öğrenciler arasında $\mathrm{p}<0,05$ anlamlılık düzeyinde 'staj motivasyonu= 0,836', 'iş ortamı $=0,370$ ', 'eğitim ve sektörel uyum $=0,279$ ', 'iş yerine karşı tutum=0,998' ve 'iş doyumu=0,262' anlamlı bir farklılığın olmadığı tespit edilmiştir. 
Tablo 5. Cinsiyet ve Değişkenler Arasındaki İlişki

\begin{tabular}{llllll}
\hline Faktörler & $\begin{array}{l}\text { Kadın } \\
\boldsymbol{n = 1 4 1}\end{array}$ & & $\begin{array}{l}\text { Erkek } \\
\boldsymbol{n = 1 7 4}\end{array}$ & \\
& Ort. & S.S & Ort. & S.S & $\boldsymbol{P}$ \\
\hline 1. İş Ortamı & 3,97 & 0,79 & 3,90 & 0,71 & 0,370 \\
2. Eğitim ve Sektörel Uyum & 3,73 & 0,79 & 3,69 & 0,83 & 0,279 \\
3. Staj Motivasyonu & 3,78 & 0,81 & 3,64 & 0,77 & 0,836 \\
4. İş Yerine Karşı Tutum & 3,39 & 0,63 & 3,43 & 0,62 & 0,998 \\
5. İş Doyumu & 3,21 & 0,79 & 3,22 & 0,76 & 0,262 \\
6. Turizmde Kariyer Seçimi & 3,92 & 0,68 & 3.92 & 0,68 & 0,526 \\
\hline
\end{tabular}
${ }^{*} p<0,05$

Tablo 6'da çalışmaya katılan öğrencilerin yaşları ( 18-22 yaş, 23-25 yaş ve 26 yaş ve üzeri) ile kariyer seçimi ve staj deneyimi alt faktörleri arasında farklılık olup olmadığını belirlemek amacıyla ANOVA testi uygulanmiştır.

Tablo 6. Yaş ile değişkenler arasında ilişki

\begin{tabular}{llllll}
\hline Faktörler & $\mathbf{1 8 - 2 2}$ yaş & \multicolumn{2}{l}{$\mathbf{2 3 - 2 5}$ yaş } & \multicolumn{2}{l}{$\mathbf{2 6}$ ve $\ddot{\text { üzeri }}$} \\
& $(\boldsymbol{a})$ & $\mathbf{( b )}$ & $\mathbf{( c )}$ & $\boldsymbol{F}$ & $\boldsymbol{P}$ \\
\hline 1. İş Yerine Karşı Tutum & 3,38 & 3,43 & 3,58 &, 608 &, 526 \\
2. Eğitim ve Sektörel Uyum & 3,73 & 3,67 & 3,85 &, 428 &, 652 \\
3. Staj Motivasyonu & 3,74 & 3,66 & 3,84 &, 608 &, 545 \\
4. İş Ortamı & 3,95 & 3,91 & 4,05 &, 258 &, 773 \\
5. İş Doyumu & 3,22 & 3,21 & 3,27 &, 053 &, 948 \\
6. Turizmde Kariyer Seçimi & 4,00 & 3,83 & 4,14 & $, 3,062$ &, 048 \\
\hline
\end{tabular}
$p<0,05^{*}, p<0,01^{* *}$

Öğrencilerin yaşları ile staj deneyimleri alt faktörleri 'işyerine karşı tutum, eğitim ve sektörel uyum, staj motivasyonu, iş ortamı ve iş doyumu' arasında anlamlı bir farklılık bulunamamıştır $(p<0,05)$. Değişkenler arasında anlamlı bir farklılık olmamasindan dolayı post hoct testi uygulanmamıştır. Genel itibari ile öğrencilerin turizm alanında kariyer seçimleri arasında kısmen anlamlı farklılık vardır $(\mathrm{p}<0,05)$. 
Tablo 7. Eğitim Durumu ve Değişkenler Arası İlişki

\begin{tabular}{llllll}
\hline Faktörler & $\begin{array}{l}\text { Önlisans } \\
\boldsymbol{n = 9 0}\end{array}$ & & $\begin{array}{l}\text { Lisans } \\
\boldsymbol{n = 2 2 5}\end{array}$ & \\
& Ort. & S.S & Ort. & S.S & $\boldsymbol{P}$ \\
\hline 1. Staj Motivasyonu & 3,69 &, 800 & 3,71 &, 791 & 0,807 \\
2. İș Yerine Karşı Tutum & 3,25 &, 601 & 3,48 &, 629 & 0,927 \\
3. İs Ortamı & 3,92 &, 702 & 3,93 &, 772 & 0,471 \\
4. İş Doyumu & 3,02 &, 594 & 3,29 &, 769 & $\mathbf{0 , 0 0 1 ^ { * }}$ \\
5. Eğitim ve Sektörel Uyum & 3,67 &, 827 & 3,72 &, 816 & 0,578 \\
6. Turizmde Kariyer Seçimi & 3,93 &, 683 & 3,91 &, 685 & 0,581 \\
\hline
\end{tabular}

${ }^{*} p<0,05$

Tablo 7' de turizm öğrencilerin eğitim durumu (önlisans - lisans) ile kariyer seçimleri arasında anlamlı bir farklılı̆̆ının olup olmadığını belirlemek amacıyla T- testi uygulanmıştır. Yapılan analiz sonucunda önlisans ve lisans öğrencilerinin staj yaptıktan sonraki sektörel görüşleri "iş doyumu" açısından anlamlı bir farklılık göstermektedir ( $\mathrm{p}<0,05=0,001)$. Staj motivasyonu, işyerine karşı tutum, iş ortamı, eğitim ve sektörel uyum, turizmde kariyer seçimi ile eğitim türü (önlisans-lisans) arasında herhangi bir farklılık bulunmamaktadır $(\mathrm{p}<0,05)$.

\section{Sonuç ve Öneriler}

Araştırmada önlisans ve lisans düzeyinde turizm eğitimi alan öğrencilerin kariyer seçimlerinde staj deneyimlerinin etkileri ele alınmıştır. Araştırmaya katılan öğrencilerin kariyer seçimlerini en çok etkileyen faktör 'staj motivasyonu' olarak belirlenmiştir $(r=529)$. Öğrencilerin iş yerindeki performansı ve grup içi etkileşim kurabilmeleri, kendilerini örgütün birer parçası olarak görmeleri çalışma motivasyonları artırarak hizmetin yoğunluğuna ve süreksiz olması temposuna uyum sağlamalarını da olumlu yönde arttırabileceğini söyleyebiliriz. Sektörde kariyer seçimlerini etkileyen en yüksek ikinci değer 'eğitim ve sektörel uyum' dur ( $r=512)$. Bu bulgu, Pehlivan (2008), Günay ve Akıncı (2017) yaptığı çalışmayla aynı sonucu vermektedir. Kariyer seçimlerine ilişkin değişkenler arası pozitif korelasyon iş ortamı ile iş yerine karşı tutum ( $\mathrm{r}=302)$ arasında kurulmuştur. 
Faktörlerin cinsiyete göre farklılığı ölçüldüğünde ise kız ve erkek öğrencilerin staj deneyiminin alt faktörleri arasında anlamlı bir farklılığın olmadığı tespit edilmiştir. Stajın kız ve erkek öğrenciler için kariyer seçimlerinde ayrımsız olarak dikkate alınması her iki grubunda yükselme ve kıdem edinme istekleri farklılık göstermeden birbirini izlemektedir. Bu durum Gürdoğan ve Atabey (2012)'de staj deneyiminin kariyer planlamasına etkisinde cinsiyet faktörünün ön plana çıtığını belirttiği çalışmasıyla paralellik göstermektedir. Eğitim durumlarına göre kariyer seçimleri arasındaki farklılık incelendiğinde ise lisans öğrencilerinin $(3,29)$ önlisans öğrencilerine $(3,02)$ göre staj deneyimi alt faktörlerinden 'iş doyumu' arasında anlamlı bir farklılığın $(p<0,05=0,001)$ olduğu tespit edilmiştir. İki yıllık turizm eğitimi alan öğrenciler ile dört yıllık turizm eğitimi alan öğrenciler iş doyumunu farklı algılamaktadır. Nitekim Türker vd., (2016) yaptığ1 çalışmada lisans öğrencilerinin turizm de kariyer planlamaya da sıcak baktıkları tespit edilmiştir. Turizm öğrencilerinin yaşları ile turizmde kariyer seçimi arasında $(\mathrm{p}<0,05=0,048)$ farklılık olduğu tespit edilmiştir. Öğrenciler sektörde staj yapmadan önce kariyer yapmaya olumlu bakarken staj yaptıktan sonra bundan vazgeçebilmektedirler.

Öğrencilerin 'iş ortamı', 'eğitim ve sektörel uyum' ve 'staj motivasyonu' değişkenlerinin yapılan çoklu regresyon analizi sonucuna $(p<0,05=p<0,00)$ düzeyinde kariyer seçimleri üzerinde etkisi olduğu sonucuna ulaşılmıştır. Kırçı'nın (2007) yaptığı çalışmasında motivasyonun kariyer seçimine etkisi olduğunu ortaya koymuştur. Ulama vd., (2015) çalışma koşullarının kariyer seçimi üzerinde etkisi olduğunu, Aymankuy ve Aymankuy (2013) ise çalışma ortamı, iş koşulları ve ücretin kariyer gelişimine pozitif etkisi olduğunu tespit etmiştir.

Günümüze kadar turizm öğrencileri ve kariyer planları - seçimleri üzerine birçok çalı̧̧malar yapılmış bazı öneri ve yöntemler sunulmasına rağmen sektörde kalma niyetleri üzerine teşvik edici yaptırım ve yatırımların yeterli olmadığı görülmektedir. Bunun en belirgin özelliği ise ' düşük ücretler', 'çalışma saatlerinin uzun, düzensiz ve stresli olması', 'mevsimsellik özelliğinden dolayı işten her an çıarılma korkusu', 'işin ekonomik kazancının yetersiz' ve 'öğrencilerin kendi iş potansiyelleri dışında getir - götür işlerinde çalıştırılmalarıdır. Bu ve bunun gibi se- 
beplerden dolayı öğrenciler staj deneyimi yaşadıktan sonra sektörde kariyer yapmak istememektedirler. Öğrenciler, sektörü çekici bir kariyer yolu olarak görmemelerinin bir diğer sebebi de kariyerlerinde önemli buldukları pek çok faktörün eksik olmasıdır.

Öğrencilerin daha kaliteli staj eğitimi alabilmeleri ve mesleği gelecek hayatlarında da idame ettirebilmeleri için işletmelere ve eğitim kurumlarına bazı öneriler sunulmuştur. Bunlar;

- Turizm öğrencilerinin sektörde istihdamına yönelik destek ve teşvik sağlanabilir.

- Stajlar, öğrencilere işi deneyimleme imkânı sunmaktadırlar. İşletmeler stajyer öğrenciler için bir program geliştirmeli ve bunu öğrenciyle paylaşmalıdır.

- İşletmeler bireylerin kariyer ve kişisel gelişimine önem vermeli bu yönde çalışmalar yapmalıdır.

- Eğitimli bireyleri işletmesinde tutmak isteyen işletmeler, yeniliklere açık, çalışan motivasyonunu önemseyen ve çalışanlarına uygun çalışma koşulları sunmalıdır.

- Öğrenciler kariyer seçimini etkileyen stajların eğitim kurumları, öğrenci ve işletmeler işbirliğinde planlanması daha yararlı olacaktır. Öğrencilerin kariyer hedefleri doğrultusunda öğrencilerle röportaj ve değerlendirmeler yapılmalıdır.

- Üniversiteler ve turizm işletmeleri arasında daha sağlam kurulmuş bir işbirliği ile staj programlarında verimli ve etkili geri bildirim sistemleri kurularak düzeltmeler ve iyileştirmeler yapılabilmelidir.

- İşletmeler stajyer öğrencileri ucuz işgücü olarak görmemeli, uluslararası standartlarda lojman imkânı sağlamalı, iş güvencesi, ücret ve sosyal haklar yönünden iyileştirmeler yapmalıdır.

- İşletme içi kararlar alınırken stajyer öğrencilerinde fikir ve gözlemleri dikkate alınarak kendilerini organizasyonun bir parçası oldukları hissettirilerek motive edilmeleri sağlanmalıdır.

- İşletme içinde diğer çalışanlara verilen yetki ve sorumluluklar stajyer öğrencilere de verilmeli ve iş üzerinde cesaretlendirilmelidirler. 
Sonuç olarak turizm sektörü varlıklarını koruyabilmeleri ve devamlılıklarını sağlayabilmeleri için turistlerin değişen istek ve ihtiyaçlarına ayak uydurmalı, gelir yönetimi, teknoloji kullanım alanları vb. yeniliklere harcadığı eforu insan kalitesi ve eğitimi gelişimine de harcamalıdırlar. 


\title{
EXTENDED ABSTRACT
}

\section{Effect of Internship Experience Career Choice: A Research on tourism students in the Thrace Region}

\author{
Bayram Akay - Seher Şıttak \\ Burdur Mehmet Akif Ersoy University - Kırklareli University
}

With the expansion of tourism in an international and national basis, the need for qualified staff to work in tourism is increasing day by day. Although there are many universities that provide tourism education in our country and a students graduate from tourism faculties every year, the sector still suffers from having the professional labor force that has received education on this business.

Along with the positive features of the tourism sector, such factors as the high turnover rate, the seasonality problem and the cheap labor force searches of the enterprises decrease the social status of the sector. After having internship experience, the sectoral approaches of students change. The effect of internship training on career choice is an undeniable fact. Completion of the internship education, experiencing the working conditions of the job in real field and the experiences obtained are important factors in choosing careers.

The purpose of the study is to determine the effects of internship experiences of undergraduate and graduate students receiving tourism education in Turkey's Thrace region (Kırklareli - Edirne - Tekirdağ) on their career choices. Sub-objectives of the research are to define the students' perceptions towards the sector, attitudes towards the sector, tendencies to make a career in the sector and motivation of internship.

Internship is an activity carried out with the aim of educating and having experience related to a profession or field of art (Güzel, 2010, p.3420). The difficult working conditions of the sector lead to the development of negative attitudes by the students against the sector and many workers that have received tourism education cannot find what they are looking 
for, cannot see a future for themselves and their career in the sector and they avoid working in the sector (Türker et al., 2016, p.313). In this case the sector should try to understand how the industrial attitudes and perceptions of tourism and hospitality students are influenced by work experience and how this experience affects their intention to make a career in the industry (Richardson, 2008, p.27). Because the individuals who are educated in tourism work in other sectors and do not build their career plans on tourism. The need for a qualified staff in the tourism industry is increasing day by day (Wang et al., 2010: 48). Introducing qualified personnel in the sector can be achieved through the capability of the tourism sector in meeting the student expectations of sector and of providing career development opportunities (Gürdoğan and Atabey, 2015, p.95). Therefore, it should be determined how the repulsive and attractive factors that students experience during the internship period affect the career choices.

Survey technique from the quantitative research methods have been used in the research. The universe of the research is composed of the associate and undergraduate students of Kurklareli Tourism Faculty and Pinarhisar Vocational School, Trakya University Applied Sciences Academy and Tekirdağ Namık Kemal University Social Sciences Vocational School Tourism and Hotel Management, located in Thrace region. The sample of the research consists of 215 undergraduate and 90 associate degree students. The research questionnaire has been applied to students who have been trained in tourism and completed at least one internship. The survey consists of three parts: demographic variables (education, gender, age), internship experience scale (internship motivation, workplace attitude, education and sectoral alignment, job satisfaction, job environment) and career choice scale. Frequency, mean $(\bar{X})$ and multiple regression analyses have been made in the research.

The fact that the Cronbach's Alpha value of career choice scale in the research is 0,73 and of internship experience scale is 0,80 shows that the research is reliable. $71,4 \%$ of the students that participate in the research are undergraduate and $28,6 \%$ of them receive associate degree education. $55.2 \%$ of the said students are male and $44.8 \%$ of them are female. In the age distribution, the age bracket of 18-22 constitutes the highest with $49,2 \%$ and 26 and above constitutes the lowest with 1,3\%. In addition, it 
has been concluded that the students are indecisive in the occupation due to the conditions of finding a job and working and their career choices are affected negatively in the sector due to the fact that the working conditions of the sector is long and tiring, the enterprise managers do not care for the employees and the seasonal characteristic of the profession.

In the research, a model has been developed to examine the effect of multiple independent variables (internship motivation, workplace attitude, education and sectoral alignment, job satisfaction, job environment) on a dependent variable (career choice) and the model test has been conducted by multiple regression analysis. According to the results obtained, the explanation rate of the model is $37 \%$. The effect of internship motivation, workplace attitude, education and sector alignment, job satisfaction and job environment on career choice is statistically significant ( $p$ $=.000<, 05)$. The order of importance of the independent variables against dependent variables is alignment with the education and sector $(\beta=, 359)$, internship motivation $(\beta=, 269)$ and job environment $(\beta=, 193)$. According to the regression coefficients, the effect of motivation of internship, job environment, education and sectoral adjustment variables on career choice is significant (Sig.000<,05). Attitude towards workplace and job satisfaction do not have a significant effect on career choice (Sig. 0,519-0,308>0,05).

It is inferred from the study that students who study tourism want to start working as qualified staff and rise their career goals. Interning students give importance to the training and the sectoral alignment, the internship motivation and the working environment in the internship experience. These factors influence career choice. The students who have not had a feasible internship experience continue their careers in the difficult sectors. As a result, the qualified worker needs of the enterprises manifest. For this, enterprises should pay attention to motivation of newly trained interns, their attitude towards work, education and sector alignment, job satisfaction and business environment. The enterprises should not see trainee students as inexpensive labor, provide public housing facilities at international standards, and should make improvements in terms of job security, wages and social rights.

The fact that the business environment in tourism is tiring and stressful is one of the reasons why the students show a negative attitude against the sector due to the seasonality characteristics. However, it can be said 
that students will be able to use their knowledge and skills in the businesses within the sector, they love the fast-paced business environment, they will reach good positions in a short time.

Similarities and differences have been found between these research results and previous researches. As a matter of fact, Türker et al. (2016) found that undergraduate students lean towards tourism and career planning. Günay and Akıncı (2017) have found that factors such as job stress and low wages are not effective on career choice. Ulama et al. (2015) have found that working conditions has an impact on career choice. Aymankuy and Aymankuy (2013) stated that students' working environment, job conditions and salary have positive effects on career development. Gürdoğan and Atabey (2012) stated that the gender factor is at the forefront of the internship experience's impact on career planning. Kırçı (2007) revealed that motivation affects career choice.

\section{Kaynakça / References}

Aksu, M. ve Bucak, T. (2012). Mesleki turizm eğitimi. Aksaray Üniversitesi İ̈BF Dergisi, 4 (2), 8-18.

Aslan, Z., Çoban, G. ve Çokal, Z. (2014). Turizm öğrencilerinin staj deneyiminde algıladıkları motivasyonun Herzberg kuramına göre değerlendirilmesi: Nevşehir Hacı Bektaş Veli üniversitesi turizm fakültesi örneği. Muğla Sıtkı Koçman Üniversitesi Sosyal Bilimler Enstitüsü Dergisi, 33, 164-188.

Aymankuy, Y. ve Aymankuy, Ş. (2013). Turizm işletmeciliği eğitimi alan öğrencilerin turizm sektöründeki istihdamla ilgili görüşleri ve sektördeki kariyer beklentileri (Balıkesir üniversitesi turizm işletmeciliği ve otelcilik yüksekokulu örneği). Akademik Bakış Dergisi, 35, 1-21.

Barbarash, D. (2016). Knowledge and skill competency volves of an undergraduate university managed cooperative intership education. Asia-Pacific Journal of Cooperative Education, 17(1), 21-30.

Çetin, Ş. (1990). Staj uygulamasına ilişkin sorunlar, 1989 turizminin genel değerlendirilmesi ve 1990'dan beklentiler sempozyumu, Aydın: Dokuz Eylül Üniversitesi Aydın TíOYO.

Çetin, Ş. (2005). Öğrenci stajlarında yararlanılan dersler üzerine ampirik bir değerlendirme: Mersin turizm işletmeciliği ve otelcilik 
yüksekokulu örneği. Anatolia: Turizm Araştırmaları Dergisi, 16(2), 153-169.

Demir, M. ve Demir, Ş. Ş. (2014). Turizm işletmelerinde yöneticilerin mesleki staj ve stajyerleri değerlendirmesi. Marmara Sosyal Araştırmalar Dergisi, 6, 19- 33.

Doğan, V. ve Yılmaz, C. (2017). Yönetim bilimleri ve pazarlama alanında bağimsiz değişkenlerin karşilaştirilmasi ve bastırıcı etki tespiti. Uluslararası Yönetim İktisat ve İsletme Dergisi, 13(2), 385 - 406.

Ergül, H. F. (2005). Motivasyon ve motivasyon teknikleri. Elektronik Sosyal Bilimler Dergisi, 4(14), 67-79.

Fong, L.H.N., Lee A.H., Luk, C. ve Law, R. (2014). How do hotel tourism students select internship employers? A segmentationapproach. Journal Of Hospitality, Leisure, Sport and Tourism Education, 15, 6879.

Francis, R. S. ve Alagas, E. N. (2017). Satisfaction towards internship programme and future career development for students in private higher education institutions: A research note. Asia-Pacific Journal of Innovation in Hospitality and Tourism, 6 (2), 69-74

Gürdoğan, A. ve Atabey, S. (2015). Öğrencilerin meslek stajından memnuniyet düzeylerinin kariyer hedeflerine etkisi. Ekonomi ve Yönetim Araştırmaları Dergisi, 4(1), 91-113.

Günay, İ ve Akıncı, Z. (2017). Turizmde sürdürülebilirlik açısından öğrencilerin sektöre karşı tutumlarının mezuniyet sonrası kariyer planlaması ve seçimine etkisi. Mehmet Akif Ersoy Üniversitesi Sosyal Bilimler Enstitüsü Dergisi, 9(20), 1-19.

Güzel, Ö. (2010). Turizm öğrencilerinin staj döneminde edindikleri motivasyonun Herzberg teorisine göre değerlendirilmesine yönelik bir araştırma. Journal of Yasar University, 20(5), 3415-3429.

Kırçı, Z. (2007). Motivasyon unsuru olarak kariyer geliştirme ve bir uygulama. Yayınlanmamış Yüksek Lisans Tezi, Atatürk Üniversitesi Sosyal Bilimler Enstitüsü İşletme Anabilim Dalı, Erzurum.

Koç, E., Yumuşak, S., Ulukoy, M., Kiliç, R., ve Toptaş, A. (2014). Are internship program sencouraging or discouraging? a viewpoint of 
tourism and hospitality students in Turkey. Journal of Hospitality, Leisure, Sport \& Tourism Education, 15, 135-142.

Köroğlu, Ö. (2011). İşgören doyumu ve turizm işletmelerinde yapılan araştırmalara ilişkin bir değerlendirme. Zkü Sosyal Bilimler Dergisi, 7(14), 246-266.

Kuşluvan, S. ve Kuşluvan, Z. (2000) Perceptions and attitudes of undergraduate tourism students towards working in the tourism industry in Turkey. Tourism Management, 21(3), 251-269.

Oral, S. (1997). Otel işletmeciliği ve otel işletmelerinde verimlilik analizleri. İzmir: Akın yılmaz Matbaası.

Richardson, S. (2008). Undergraduate tourism and hospitality students attitudes toward a career in the industry: A preliminary investigation. Journal Of Teaching In Travel \& Tourism, 8 (1), 23-46.

Richardson, S., ve Butler, G. (2012). Attitudes of Malaysian tourism and hospitality students towards a career in the industry. Asia Pacific Journal of Tourism Research, 17(3), 262-276.

Saruhan, Ş. C. (1986). 'Turizm sektöründe personel eğitimi araştırması içinde turizm yıllığı', Ankara: Turizm Bankası Yayını, s.171-180

Seymen, O., Bolat, T., Bolat, İ. O. ve Kinter, O. (2017). Turizm sektöründe çalışma koşulları algısı, hizmet verme yatkınlı̆̆ ve mesleki yabancılaşma ilişkisi: Turizm eğitimi alan öğrenciler açısından bir değerlendirme. MANAS Sosyal Araştırmalar Dergisi, 6(3), 402 - 430

Sezgin, İ. (1988). Turizm sektöründe becerili ve teknik işgücünün yetiştirilmesi, Tebliğ, Ankara.

Tarlan, D. ve Tütüncü, Ö. (2001). Konaklama işletmelerinde başarım değerlemesi ve işdoyumu analizi. Dokuz Eylül Üniversitesi Sosyal Bilimler Enstitüsü Dergisi, 3(2), 141-163.

Türk Dil Kurumu (TDK) (2018). Staj nedir?, http://www.tdk.gov.tr/index.php?option=com_gts\&kelime=STAJ Erişim Tarihi: 02.08.2018

Türkiye İstatistik Kurumu (TUIK) (2019), Türkiye işsizlik oranı ve istihdam https://biruni.tuik.gov.tr/medas/?kn=72\&locale=tr Erişim Tarihi: 26.04.2019

Türkiye Seyahat Acentaları Birliği (TÜRSAB) (2019), Türkiye turizm gelirleri GSMH içindeki yeri https://www.tursab.org.tr/istatistikler/turizmin-ekonomideki-yeri Erişim Tarihi: 26.04.2019 
Türkiye Seyahat Acentaları Birliği (TÜRSAB) (2019), Ülkemize gelen turist sayis1 https://www.tursab.org.tr/tr/turizm-verileri/istatistikler/turist-sayisi-ve-turizm-geliri/2003-2018-gelirsayi-veortalama-harcama 68.html Erişim Tarihi: 26.04.2019

Türker, N., Uçar, M. ve Ateş, A. M. (2016). Turizm eğitimi alan öğrencilerin turizm sektörü algıları: Karabük üniversitesi öğrencileri üzerine bir araştırma. Karabük Üniversitesi Sosyal Bilimler Enstitüsü Dergisi, 6 (2), 311-333.

Ulama, Ş., Batman, O. ve Ulama, H. (2015). Lisans düzeyinde turizm eğitimi alan öğrencilerin kariyer algılamalarına yönelik bir araştırma: Sakarya üniversitesi örneği. Bartın Üniversitesi İ.I.B.F. Dergisi, 6(12), 339-369.

Wang, J., Huyton, J., Gao, X. ve Ayres, H. (2010). Evaluating undergraduate courses in tourism management: A comparison between Australia And China". Journal Of Hospitality, Leisure, Sport And Tourism Education, 9( 2), 46-62.

World Travel and Tourism Council (WTTC) (2019). Türkiye işsizlik oranı ve istihdamin geleceği https://www.wttc.org/about/mediacentre/press-releases/press-releases/2019/turkey-tops-europeantravel-and-tourism-growth-ranking-in-2018/ Erişim Tarihi: 26.04.2019

Yaşlıoğlu, M. M. (2017). Sosyal bilimlerde faktör analizi ve geçerlilik: Keşfedici ve doğrulayıcı faktör analizlerinin kullanılması. İstanbul Üniversitesi İşletme Fakültesi Dergisi, 46, 74-85.

\section{Kaynakça Bilgisi / Citation Information}

Akay, B. ve Şıttak, S. (2019). Staj deneyiminin kariyer seçimine etkisi: Trakya bölgesi'ndeki turizm öğrencilerine yönelik bir araştırma. OPUS-Uluslararası Toplum Araştırmaları Dergisi, 11(18), 757-784. DOI: 10.26466/opus.533956 